\title{
Hydroxypyruvate Reductase Activity in Paracoccus denitrificans
}

\author{
By C. W. BAMFORTH AND J. R. QUAYLE \\ Department of Microbiology, University of Sheffield, Sheffield Sio 2TN
}

(Received 4 April 1977)

Extracts of Paracoccus denitrificans contain NADP-linked hydroxypyruvate reductase activity. The enzyme responsible has been separated and partially purified. It showed some activity with glyoxylate, acetoin, diacetyl and oxaloacetate and was $2 \frac{1}{2}$ times as active with NADP as with NAD. It appears to be a constitutive enzyme and possible metabolic roles for it are discussed. Attention is drawn to the dangers of relying solely on the presence of hydroxypyruvate reductase as a diagnostic marker for the operation of a serine pathway of $\mathrm{C}_{\mathrm{I}}$-assimilation in a micro-organism. The malate dehydrogenase from $\mathrm{Pa}$. denitrificans has been partially purified and shown to possess no glycerate dehydrogenase or hydroxypyruvate reductase activity.

\section{INTRODUCTION}

Extracts of Paracoccus denitrificans grown on several carbon substrates contain an apparent pyridine nucleotide-linked hydroxypyruvate reductase activity for which there is no obvious metabolic role (Gibbs, I966; Blackmore \& Quayle, I970; Cox \& Quayle, 1975). Included amongst such growth substrates is methanol and this might suggest the operation of a serine pathway, although the enzyme profile of the organism indicates that growth on this substrate is autotrophic (Cox \& Quayle, 1975). Since hydroxypyruvate reductase is widely used as a marker enzyme diagnostic of the serine pathway of $\mathrm{C}_{1}$-assimilation, its apparent presence in a methanol-grown organism, despite its apparent lack of function, signals a need for caution and raises the question whether it is indeed a hydroxypyruvate reductase or some other relatively non-specific enzyme. The aim of the present investigation was to characterize the enzyme responsible.

\section{METHODS}

Chemicals. All chemicals were of analytical reagent grade where possible. Phosphohydroxypyruvic acid was prepared from the cyclohexylammonium salt of the dimethyl ketal derivative (Calbiochem) as described by Heptinstall \& Quayle (1970). All purified enzymes were obtained from Boehringer. Buffer solutions were prepared as described by Dawson et al. (1969).

Maintenance and growth of organisms. Paracoccus denitrificans (NCrB8944) was maintained and grown as previously described (Cox \& Quayle, 1975), using $50 \mathrm{~mm}$-methanol as carbon source, unless otherwise stated.

Preparation of crude extracts. Organisms were harvested by centrifugation ( $5000 \mathrm{~g}, 20 \mathrm{~min}$ ), washed once in $50 \mathrm{mM}-\mathrm{KH}_{2} \mathrm{PO}_{4} / \mathrm{KOH}$ buffer, $\mathrm{pH} 7{ }_{7}^{\circ}$, and resuspended in 5 vol. of the same buffer. Ice-cold cell suspensions were disrupted by sonication in an MSE disintegrator (150 W) for six successive periods of $30 \mathrm{~s}$, interspersed with cooling periods, followed by centrifugation $\left(38000 \mathrm{~g}, 20 \mathrm{~min}, 2^{\circ} \mathrm{C}\right)$. The resulting supernatant is referred to as 'crude extract'.

Enzyme assays. All enzyme assays were done at $30^{\circ} \mathrm{C}$ using Pye Unicam SPI 800 or Beckman DB-GT double-beam recording spectrophotometers.

Hydroxypyruvate reductase [D-glycerate: $\mathrm{NAD}(\mathrm{P})^{+}$2-oxidoreductase, $\mathrm{EC}$ 1.1.1.8I] was assayed in a reaction mixture (total vol., $3 \mathrm{ml}$ ) containing: $300 \mu \mathrm{mol}$ acetic acid/NaOH buffer, $\mathrm{pH} 5 \cdot 0 . \mathrm{KH}_{2} \mathrm{PO}_{4} /$ 
$\mathrm{KOH}$ buffer, $\mathrm{pH} 7.0 ; 2 \mu \mathrm{mol}$ lithium hydroxypyruvate; $0.4 \mu \mathrm{mol}$ NAD(P)H. Reactions were started by addition of hydroxypyruvate and followed spectrophotometrically at $340 \mathrm{~nm}$. In crude extracts, $3 \mu \mathrm{mol}$ KCN was added to inhibit NADH oxidase activity.

Oxaloacetate reductase [malate dehydrogenase; L-malate: $\mathrm{NAD}(\mathrm{P})^{+}$oxidoreductase, EC I.I.1.82] was assayed by a method similar to that for hydroxypyruvate reductase, except for the substitution of I $\mu \mathrm{mol}$ oxaloacetic acid in place of hydroxypyruvate.

The following enzymes were assayed by previously published methods: phosphohydroxypyruvate reductase [3-phosphoglycerate: $\mathrm{NAD}^{+}$2-oxidoreductase, EC 1 . I . I .95] (Pizer \& Sugimoto, 1971); phosphoserine aminotransferase ( $O$-phospho-L-serine:2-oxoglutarate aminotransferase, EC 2.6.1.52] (Hirsch-Kolb \& Greenberg, 1971); phosphoserine phosphatase ( $O$-phosphoserine phosphohydrolase, EC 3. I . 3 . 3] (Heptinstall \& Quayle, 1970).

Enzyme units. One enzyme unit is the amount of enzyme that catalyses the transformation of $\mathrm{I} \mu \mathrm{mol}$ substrate $\mathrm{min}^{-1}$ (or the formation of I $\mu$ mol product $\min ^{-1}$ ) at $30^{\circ} \mathrm{C}$ under the assay conditions described.

Protein determination. Protein was estimated by the Folin-Ciocalteu method as described by Lowry et al. (1951) with bovine serum albumin, dried to constant weight, as standard.

Partial purification of hydroxypyruvate reductase from Pa. denitrificans. Step I : protamine sulphate treatment. To the crude extract at $4{ }^{\circ} \mathrm{C}$ was added $33 \%(\mathrm{v} / \mathrm{v})$ of a $2 \%(\mathrm{w} / \mathrm{v})$ solution of protamine sulphate. The mixture was stirred for $20 \mathrm{~min}$ and centrifuged $\left(38000 \mathrm{~g}, 20 \mathrm{~min}, 2{ }^{\circ} \mathrm{C}\right)$.

Step 2: first ammonium sulphate treatment. The supernatant from step I was taken to $50 \%$ of saturation with $\left(\mathrm{NH}_{4}\right)_{2} \mathrm{SO}_{4}$ by the slow addition of solid $\left(\mathrm{NH}_{4}\right)_{2} \mathrm{SO}_{4}$ at $4{ }^{\circ} \mathrm{C}$. The table of Dixon (I953a) was used to compute the amount of $\left(\mathrm{NH}_{4}\right)_{2} \mathrm{SO}_{4}$ required. After equilibration at $4{ }^{\circ} \mathrm{C}$ for $20 \mathrm{~min}$, the mixture was centrifuged $\left(38000 \mathrm{~g}, 20 \mathrm{~min}, 4^{\circ} \mathrm{C}\right)$ and the pellet was redissolved in a minimum volume of $50 \mathrm{~mm}$-potassium phosphate, $\mathrm{pH} 7 \cdot 0$.

Step 3: hydroxylapatite chromatography. The redissolved pellet was applied at $4{ }^{\circ} \mathrm{C}$ to a column of hydroxylapatite (Bio-Rad Bio-Gel HTP; $2 \times 3 \mathrm{~cm}$ ) previously washed with $50 \mathrm{mM}$-potassium phosphate, $\mathrm{pH} 7 \cdot 0$. The enzyme did not bind and was eluted with the same buffer.

Step 4: second ammonium sulphate treatment. The active eluate from step 3 was taken to $30 \%$ of saturation with $\left(\mathrm{NH}_{4}\right)_{2} \mathrm{SO}_{4}$ as described above and the resulting precipitate was discarded. The supernatant was taken successively to $40 \%$ and $50 \%$ of saturation with $\left(\mathrm{NH}_{4}\right)_{2} \mathrm{SO}_{4}$ and the redissolved precipitates (which both contained hydroxypyruvate reductase activity) were pooled.

Step 5: Sephadex G-1 50 chromatography. The combined redissolved pellets from step 4 (4 ml) were applied to a column of Sephadex G-I $50(2 \times 32 \mathrm{~cm})$ previously equilibrated with $50 \mathrm{~mm}$-potassium phosphate, $\mathrm{pH} 7 \cdot 0$. The column was eluted with the same buffer at $4{ }^{\circ} \mathrm{C}$. Fractions $(4 \mathrm{ml})$ were collected and those showing significant hydroxypyruvate reductase activity were pooled and stored at $-15^{\circ} \mathrm{C}$.

Partial purification of oxaloacetate reductase (malate dehydrogenase) from Pa. denitrificans. Step 2: first ammonium sulphate treatment. The supernatant from step 2 of the above purification procedure [i.e. that material not sedimented at $50 \%$ of saturation with $\left(\mathrm{NH}_{4}\right)_{2} \mathrm{SO}_{4}$ ] was taken to $85 \%$ of saturation with $\left(\mathrm{NH}_{4}\right)_{2} \mathrm{SO}_{4}$ as described above; the resulting pellet was redissolved in a minimum volume of $50 \mathrm{mM}$-potassium phosphate, $\mathrm{pH} 7 \cdot 0$.

Step 3: hydroxylapatite chromatography. This was performed in a similar manner to that described in step 3 above.

Step 4: second ammonium sulphate treatment. The active eluate from step 3 was taken successively from o to $50 \%$, 50 to $60 \%$ and 60 to $70 \%$ of saturation with $\left(\mathrm{NH}_{4}\right)_{2} \mathrm{SO}_{4}$ as described above. Malate dehydrogenase was precipitated in the last two fractions and the appropriate redissolved pellets were pooled and dialysed at $4{ }^{\circ} \mathrm{C}$ for $2 \mathrm{~h}$ against I 1 Io mM-potassium phosphate, $\mathrm{pH} 7 \cdot 0$.

Step 5: ion-exchange chromatography. The dialysed enzyme from step 4 was applied to a column $(1 \cdot 5 \times$ $4 \mathrm{~cm}$ ) of DEAE-cellulose (Whatman DE-52) previously washed with $10 \mathrm{mM}$-potassium phosphate, $\mathrm{pH} 7 \cdot 0$. The column was then successively eluted at $4{ }^{\circ} \mathrm{C}$, with $10,50,100,150$ and 200 mM-potassium phosphate, $\mathrm{pH} 7 \cdot 0$. The malate dehydrogenase was eluted by $100 \mathrm{mM}$-phosphate.

Polyacrylamide gel electrophoresis. This was performed according to the method of Davis (1964) without the use of a large pore gel. Gels ( $7 \%$ w/v) were used at $\mathrm{pH} 8.3$. Bromophenol blue (I ml of $0.01 \%$, w/v) was used as tracking dye; electrophoresis was carried out at $2 \mathrm{~mA}$ per tube until the dye had almost left the base of the gel (about $2 \mathrm{~h})$. Gels were fixed in $7 \%(\mathrm{v} / \mathrm{v})$ acetic acid and stained using $0.05 \%(\mathrm{w} / \mathrm{v})$ Naphthalene Black $12 B$ in the same solvent. After staining for at least $\mathrm{I} h$, excess dye was removed by washing overnight in $7 \%(\mathrm{v} / \mathrm{v})$ acetic acid. Glycerate dehydrogenase activity was located in unfixed gels using the mixture: $\mathrm{I} .0 \mathrm{ml} 200 \mathrm{mM}$-potassium phosphate, $\mathrm{pH} 7.0 ; 0.2 \mathrm{ml} 0.8 \%(\mathrm{w} / \mathrm{v})$ Nitrobluetetrazolium; $0.1 \mathrm{ml} 33 \mathrm{mM}-$ phenazine methosulphate; $\mathrm{O} \cdot \mathrm{I} \mathrm{ml} 4 \mathrm{mM}-\mathrm{NAD}(\mathrm{P}) \mathrm{H} ; \mathrm{O}^{\circ}$ I $\mathrm{ml}$ IOO $\mathrm{mM}$-DL-glycerate; and enough water to cover the gel. Malate dehydrogenase was located using the same mixture except for the replacement of glycerate by DL-malic acid. 


\section{RESULTS}

Separation of hydroxypyruvate reductase and oxaloacetate reductase (malate dehydrogenase) from $\mathrm{Pa}$. denitrificans

Preliminary work had shown that the NAD(P)H-linked hydroxypyruvate reductase showed activity with oxaloacetate. Cell-free extracts of $P a$. denitrificans also contained very high activities of NAD(P)-linked malate dehydrogenase. In view of the activity of the hydroxypyruvate reductase with respect to oxaloacetate, there seemed a possibility that the malate dehydrogenase, working in reverse, might also be able to reduce hydroxypyruvate, thus contributing to the overall hydroxypyruvate reductase activity measured in crude extracts. In order to check this possibility, both enzymes were partially purified from the same extract of methanol-grown $P$ a. denitrificans (Tables I and 2). NADPH was the preferred reductant for the hydroxypyruvate reductase, the ratio of activities with NADPH and NADH in the most purified fraction being $2.45: \mathrm{I}$. In contrast, NADH was the preferred electron donor for the oxaloacetate reduction, the ratio of activities with NADH and NADPH in the most purified fraction being $20.4: \mathrm{I}$. The fact that both ratios remained fairly constant during the respective purifications implied that single enzymes were involved.

The purified oxaloacetate reductase showed no detectable activity with hydroxypyruvate as substrate, with either NADH or NADPH as reductant. It is clear therefore that this enzyme is more properly termed a malate dehydrogenase. The purified hydroxypyruvate reductase showed activity with oxaloacetate as substrate. The ratio of the activities of NADPH-linked hydroxypyruvate reductase to that of NADPH-linked oxaloacetate reductase in the most purified fraction was $3 \cdot 3: \mathrm{I}$.

Relative thermal stabilities of hydroxypyruvate reductase and malate dehydrogenase. The two enzymes, measured as NADPH-dependent reduction of hydroxypyruvate and NADH-dependent reduction of oxaloacetate respectively at $\mathrm{pH} 7 \cdot 0$, showed markedly different stabilities when heated at $42^{\circ} \mathrm{C}$ in $50 \mathrm{~mm}$-phosphate buffer, $\mathrm{pH} 7 \cdot 0$. The half-life of the former enzyme was approximately $35 \mathrm{~min}$, that of the latter enzyme was approximately 3 min.

Purity of hydroxypyruvate reductase and malate dehydrogenase. Partially purified hydroxypyruvate reductase (after step 5, Table I) showed I 2 to I4 protein bands on polyacrylamide gels at $\mathrm{pH} \mathrm{8.3.} \mathrm{Of} \mathrm{these,} \mathrm{two} \mathrm{showed} \mathrm{glycerate:} \mathrm{NAD}(\mathrm{P})^{+}$-dependent reduction of Nitrobluetetrazolium in the presence of phenazine methosulphate (Table 3). Both bands also showed activity with malate as electron donor and there was an additional, slower moving band $\left(R_{F} 0.44\right)$ of malate: NAD ${ }^{+}$dehydrogenase activity. If the enzyme extract was heated to $40{ }^{\circ} \mathrm{C}$ for $30 \mathrm{~min}$ prior to loading on to the gel, the slower moving band of malate: $\mathrm{NAD}^{+}$ dehydrogenase activity $\left(R_{F} 0.44\right)$ did not appear, whereas the two faster bands still appeared.

Partially purified malate dehydrogenase (after step 5, Table 2) showed seven bands after protein-staining of the gels. Three of these gave DL- or L-malate-dependent deposition of formazan in the presence of $\mathrm{NAD}^{+}$(though not NADP ${ }^{+}$) and phenazine methosulphate; no band showed activity with glycerate as electron donor (Table 3 ). This rules out the possibility that the band with $R_{F}$ value of 0.67 from the malate dehydrogenase preparation is identical with that of $R_{F}$ value 0.63 from the hydroxypyruvate reductase preparation. Prior heating of the enzyme extract abolished or diminished appearance of the bands at $R_{F} 0.39$ and 0.67 .

The results of this experiment confirm those obtained during the enzyme purification procedures and heat stability tests and indicate that $\mathrm{Pa}$. denitrificans possesses separate malate dehydrogenase and hydroxypyruvate reductase enzymes. The former enzyme was heat-labile and catalysed the oxidation of malate by NAD ${ }^{+}$or $\mathrm{NADP}^{+}$; the latter enzyme was heat-stable and catalysed the oxidation of both glycerate and malate by $\mathrm{NADP}^{+}$or $\mathrm{NAD}^{+}$. 
Table I. Purification of hydroxypyruvate reductase from $P$ a. denitrificans

The crude extract was prepared from $3 \mathrm{~g}$ cell paste of the methanol-grown organism suspended in $25 \mathrm{ml} 50 \mathrm{mM}-\mathrm{KH}_{2} \mathrm{PO}_{4} / \mathrm{K}_{2} \mathrm{HPO}_{4}$ buffer, $\mathrm{pH} 7 \cdot 0$. Hydroxypyruvate reductase assays were performed at pH 7.0, with both NADPH and NADH as electron donors, as described in Methods.

\begin{tabular}{|c|c|c|c|c|c|c|c|c|c|}
\hline \multirow[b]{2}{*}{ Step } & \multirow[b]{2}{*}{$\begin{array}{l}\text { Volume } \\
\text { (ml) }\end{array}$} & \multirow[b]{2}{*}{$\begin{array}{l}\text { Total } \\
\text { protein } \\
\text { (mg) }\end{array}$} & \multicolumn{2}{|c|}{$\begin{array}{c}\text { Enzyme activity with } \\
\text { NADPH }\end{array}$} & \multicolumn{2}{|c|}{$\begin{array}{c}\text { Enzyme activity with } \\
\text { NADH }\end{array}$} & \multirow[b]{2}{*}{$\begin{array}{l}\text { Sp. activity } \\
\text { (NADPH) } \\
\text { Sp. activity } \\
\text { (NADH) }\end{array}$} & \multirow[b]{2}{*}{$\begin{array}{l}\text { Purification } \\
\text { (NADPH) }\end{array}$} & \multirow[b]{2}{*}{$\begin{array}{l}\text { Yield } \\
(\%)\end{array}$} \\
\hline & & & $\begin{array}{c}\text { Total } \\
\text { activity } \\
\text { (munits) }\end{array}$ & $\begin{array}{l}\text { Sp. activity } \\
\text { (munits } \\
\mathrm{mg}^{-1} \text { ) }\end{array}$ & $\begin{array}{c}\text { Total } \\
\text { activity } \\
\text { (munits) }\end{array}$ & $\begin{array}{l}\text { Sp. activity } \\
\text { (munits } \\
\mathrm{mg}^{-1} \text { ) }\end{array}$ & & & \\
\hline Crude extract & 30 & 600 & 31200 & $52 \cdot 0$ & 18500 & $30 \cdot 8$ & $1 \cdot 69$ & I & 100 \\
\hline I. Protamine sulphate treatment & $32 \cdot 5$ & 530 & 27200 & $5 I \cdot 3$ & 14400 & $27 \cdot 2$ & $1 \cdot 89$ & 0.99 & $87 \cdot 2$ \\
\hline 2. 0 to $50 \%\left(\mathrm{NH}_{4}\right)_{2} \mathrm{SO}_{4}$ fraction & $4 \cdot 3$ & 183 & 12986 & $7 I \cdot 0$ & 5289 & $28 \cdot 9$ & $2 \cdot 46$ & $1 \cdot 36$ & $4 I \cdot 6$ \\
\hline 3. Hydroxylapatite chromatography & $24 \cdot 2$ & 90 & 13552 & $150 \cdot 6$ & 7018 & $78 \cdot 0$ & $1 \cdot 93$ & $2 \cdot 90$ & $43 \cdot 4$ \\
\hline 4. 30 to $50 \%\left(\mathrm{NH}_{4}\right)_{2} \mathrm{SO}_{4}$ fraction & $3 \cdot 2$ & 33 & 6592 & $199 \cdot 8$ & 3616 & $109 \cdot 6$ & $1 \cdot 82$ & $3 \cdot 84$ & $2 I \cdot I$ \\
\hline 5. Sephadex G-I 50 chromatography & 30 & II $\cdot 7$ & 3900 & $333 \cdot 3$ & 1590 & $135 \cdot 9$ & 2.45 & 6.41 & 12.5 \\
\hline
\end{tabular}

Table 2. Purification of oxaloacetate reductase (malate dehydrogenase) from Pa. denitrificans

The crude extract used was that described in Table I. Oxaloacetate reductase assays were performed at $\mathrm{pH} 7 \cdot 0$, with oxaloacetate as carbon substrate and with both NADPH and NADH as electron donors, as described in Methods.

\begin{tabular}{|c|c|c|c|c|c|c|c|c|c|}
\hline \multirow[b]{2}{*}{ Step } & \multirow[b]{2}{*}{$\begin{array}{l}\text { Volume } \\
(\mathrm{ml})\end{array}$} & \multirow[b]{2}{*}{$\begin{array}{l}\text { Total } \\
\text { protein } \\
(\mathrm{mg})\end{array}$} & \multicolumn{2}{|c|}{$\begin{array}{c}\text { Enzyme activity with } \\
\text { NADH }\end{array}$} & \multicolumn{2}{|c|}{$\begin{array}{l}\text { Enzyme activity with } \\
\text { NADPH }\end{array}$} & $\begin{array}{l}\text { Sp. activity } \\
\text { (NADH) }\end{array}$ & \multirow[b]{2}{*}{$\begin{array}{l}\text { Purification } \\
\text { (NADH) }\end{array}$} & \multirow[b]{2}{*}{$\begin{array}{l}\text { Yield } \\
(\%)\end{array}$} \\
\hline & & & $\begin{array}{c}\text { Total } \\
\text { activity } \\
\text { (units) }\end{array}$ & $\begin{array}{l}\text { Sp. activity } \\
\text { (units } \mathrm{mg}^{-1} \text { ) }\end{array}$ & $\begin{array}{l}\text { Total } \\
\text { activity } \\
\text { (units) }\end{array}$ & $\begin{array}{l}\text { Sp. activity } \\
\text { (units } \mathrm{mg}^{-1} \text { ) }\end{array}$ & 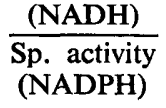 & & \\
\hline Crude extract & 30 & 600 & I $64 \mathrm{I}$ & $2 \cdot 74$ & 68 & 0.11 & $24 \cdot 9$ & $\mathbf{I}$ & IOO \\
\hline I. Protamine sulphate treatment & $32 \cdot 5$ & 530 & I $25 \mathrm{I}$ & $2 \cdot 36$ & $53 \cdot 0$ & $0 \cdot 10$ & $23 \cdot 6$ & 0.86 & 76 \\
\hline 2. 50 to $85 \%\left(\mathrm{NH}_{4}\right)_{2} \mathrm{SO}_{4}$ fraction & 3.9 & 102 & $554 \cdot 6$ & $5 \cdot 44$ & $10 \cdot I$ & $0 \cdot 10$ & $54 \cdot 4$ & I.99 & 34 \\
\hline 3. Hydroxylapatite chromatography & $25 \cdot 0$ & $4 \mathrm{I}$ & 290.0 & 7.07 & II 3 & 0.28 & $25 \cdot 3$ & $2 \cdot 58$ & 18 \\
\hline 4. 50 to $70 \%\left(\mathrm{NH}_{4}\right)_{2} \mathrm{SO}_{4}$ fraction & $\begin{array}{l}4 \cdot 0 \\
4 \cdot 6\end{array}$ & $\begin{array}{l}10 \cdot 8 \\
1 \cdot 06\end{array}$ & $\begin{array}{r}117 \cdot 4 \\
60 \cdot 5\end{array}$ & 10.8 & $5 \cdot 1$ & 0.47 & $23 \cdot 0$ & $3 \cdot 94$ & $7 \cdot 2$ \\
\hline
\end{tabular}




\section{Table 3. Polyacrylamide gel electrophoresis of hydroxypyruvate reductase and malate dehydrogenase}

Samples of fraction 5, Table I ( $78 \mu \mathrm{g}$ protein) and fraction 5, Table 2 (23 $\mu \mathrm{g}$ protein) were subjected to electrophoresis and protein and enzyme bands were detected as described in Methods.

\begin{tabular}{|c|c|c|c|c|}
\hline \multirow[b]{2}{*}{ Sample subjected to electrophoresis } & \multicolumn{4}{|c|}{$\begin{array}{c}R_{F} \text { (relative to bromophenol blue) } \\
\text { Enzyme substrates }\end{array}$} \\
\hline & $\begin{array}{c}\text { Glycerate } \\
\text { NAD }^{+}\end{array}$ & $\begin{array}{c}\text { Glycerate } \\
\text { NADP }^{+}\end{array}$ & $\begin{array}{l}\text { Malate } \\
\text { NAD }^{+}\end{array}$ & $\begin{array}{l}\text { Malate } \\
\text { NADP }^{+}\end{array}$ \\
\hline Hydroxypyruvate reductase & $\begin{array}{l}0.64 \\
0.86\end{array}$ & $\begin{array}{l}0.63 \\
0.85\end{array}$ & $\begin{array}{l}0.44 \\
0.63 \\
0.84\end{array}$ & $\begin{array}{l}0.63 \\
0.84\end{array}$ \\
\hline $\begin{array}{l}\text { Hydroxypyruvate reductase heated } \\
\text { to } 40^{\circ} \mathrm{C} \text { for } 30 \mathrm{~min}\end{array}$ & $\begin{array}{l}\text { NT } \\
\text { NT }\end{array}$ & $\begin{array}{l}0.64 \\
0.86\end{array}$ & $\begin{array}{l}0.62 \\
0.84\end{array}$ & $\begin{array}{l}0.63 \\
0.83\end{array}$ \\
\hline Malate dehydrogenase & No bands & No bands & $\begin{array}{l}0.39 \\
0.51 \\
0.67\end{array}$ & No bands \\
\hline $\begin{array}{l}\text { Malate dehydrogenase heated } \\
\text { to } 40^{\circ} \mathrm{C} \text { for } 30 \mathrm{~min}\end{array}$ & NT & NT & $\begin{array}{c}0.52 \\
0.65 \\
\text { (very faint) }\end{array}$ & $\begin{array}{c}0.69 \\
\text { (very faint) }\end{array}$ \\
\hline
\end{tabular}

\section{Properties of hydroxypyruvate reductase from $\mathrm{Pa}$. denitrificans}

pH optimum. The $\mathrm{pH} /$ activity curve showed a sharp peak at $\mathrm{pH} 5$, which is similar to values previously reported for similar enzymes (Large \& Quayle, 1963; Kohn \& Jakoby, I968 $b$; Large \& Carter, 1973). This contrasts with a broad pH optimum of approximately 8 for the NADH-linked oxaloacetate reductase.

Effect of substrate concentration. When determined at $\mathrm{pH} 5.0$ and $\mathrm{I} 30 \mu \mathrm{M}-\mathrm{NADPH}$, an apparent $K_{\mathrm{m}}$ value of $100 \mu \mathrm{M}$ was obtained for hydroxypyruvate by the method of Eisenthal \& Cornish-Bowden (1974). There was substrate inhibition at concentrations of hydroxypyruvate above $330 \mu \mathrm{M}$. At $670 \mu \mathrm{M}$-hydroxypyruvate apparent $K_{\mathrm{m}}$ values of I 8 and I I $2 \mu \mathrm{M}$ respectively were obtained for NADPH and NADH. Substrate inhibition occurred at NADPH concentrations greater than $70 \mu \mathrm{M}$. In all determinations $V_{\max }$ was 0.65 to 0.75 $\mu \mathrm{mol}$ nicotinamide nucleotide oxidized $\mathrm{min}^{-1}$ (mg protein) ${ }^{-1}$. The apparent $K_{\mathrm{m}}$ values are in good agreement with those obtained for the constitutive hydroxypyruvate reductase from Pseudomonas acidovorans by Kohn \& Jakoby (1968b).

Substrate specificity. No other substrate tested under the standard assay conditions was as active as hydroxypyruvate, although glyoxylate, acetoin and diacetyl at high concentrations showed some activity (Table 4 ). Oxaloacetate was reduced at about one-third the rate of hydroxypyruvate.

That each of the activities reported in Table 4 (except the total oxaloacetate reductase activity) was due to the hydroxypyruvate reductase is suggested by the observation that heating of the enzyme preparation to $40{ }^{\circ} \mathrm{C}$ for $30 \mathrm{~min}$ led to a 10 to $25 \%$ loss of activity with each of the listed substrates. In the case of oxaloacetate reductase activity, $79 \%$ was lost during the heat treatment. This indicates the presence in the preparation of some heatlabile enzyme, probably the malate dehydrogenase running at $R_{F} 0.44$ in polyacrylamide gel electrophoresis (Table 3 ). The oxaloacetate reductase activity remaining in the enzyme preparation after heating may be ascribed to the heat-stable hydroxypyruvate reductase, running at $\boldsymbol{R}_{F} 0.63$ and 0.85 during electrophoresis (Table 3). The enzyme staining of the gels showed that the heat-stable glycerate dehydrogenase also possessed heat-stable malate dehydrogenase activity. It therefore seems likely from the data in Tables 3 and 4 that the hydroxypyruvate reductase can itself reduce oxaloacetate at approximately one-tenth the rate of hydroxypyruvate. 
Table 4. Substrate specificity of hydroxypyruvate reductase

All substrates were tested in the standard assay mixture at $\mathrm{pH} 5.0$ and using NADPH as electron donor. The specific activity of the enzyme with hydroxypyruvate as substrate was $330 \mathrm{nmol}$ NADPH consumed $\mathrm{min}^{-1}$ (mg protein) ${ }^{-1}$.

\begin{tabular}{|c|c|c|}
\hline Substrate & $\begin{array}{l}\text { Final concn } \\
(\mathrm{mM})\end{array}$ & $\begin{array}{c}\text { Relative } \\
\text { activity } \\
(\%)\end{array}$ \\
\hline Hydroxypyruvate & 0.67 & 100 \\
\hline Acetoin & $\begin{array}{r}3 \cdot 3 \\
33 \cdot 0\end{array}$ & $\begin{array}{l}13 \\
\text { I4 }\end{array}$ \\
\hline Diacetyl & $\begin{array}{r}3 \cdot 3 \\
33 \cdot 0\end{array}$ & $\begin{array}{l}13 \\
12\end{array}$ \\
\hline Glyoxylate & $\begin{array}{r}3 \cdot 3 \\
33 \cdot 0\end{array}$ & $\begin{array}{r}5 \\
15\end{array}$ \\
\hline Methylglyoxal & $\begin{array}{r}3 \cdot 3 \\
33 \cdot 0\end{array}$ & $\begin{array}{l}3 \\
5\end{array}$ \\
\hline Acetaldehyde & $\begin{array}{r}3 \cdot 3 \\
33 \cdot 0\end{array}$ & $\begin{array}{l}3 \\
3\end{array}$ \\
\hline Glyoxal & $\begin{array}{r}3 \cdot 3 \\
33 \cdot 0\end{array}$ & $\begin{array}{l}3 \\
3\end{array}$ \\
\hline Oxaloacetate & 0.33 & 32 \\
\hline
\end{tabular}

Pyruvate, acetone, formaldehyde, glycolaldehyde, DL-glyceraldehyde, acetoacetate, dihydroxyacetone and 2-oxoglutarate were not substrates.

Stability. Hydroxypyruvate reductase lost activity slowly on storage at $-15{ }^{\circ} \mathrm{C}$ interspersed with frequent thawing and re-freezing. Approximately $20 \%$ of the activity was lost over eight cycles of freezing and thawing.

Effect of anions. Citrate was an inhibitor of hydroxypyruvate reductase, and was competitive with respect to hydroxypyruvate $\left[K_{\mathrm{i}}=32 \mathrm{mM}\right.$, determined by the method of Dixon $(1953 b)$ under standard assay conditions at $\mathrm{pH} 7 \cdot 0]$. Bromide and iodide at $33 \mathrm{~mm}$ inhibited the enzyme by $38 \%$ and $39 \%$ respectively. This is in marked contrast to the hydroxypyruvate reductase of $P$ s. acidovorans described by Kohn \& Jakoby (I968b) which was activated by similar concentrations of bromide and iodide.

Reverse reaction. The reaction catalysed by hydroxypyruvate reductase could readily be reversed, particularly at higher $\mathrm{pH}$ values. With $3.3 \mathrm{~mm}$-DL-glycerate and $0.13 \mathrm{mM}^{-N_{A D P}+}$ as substrates, a rate of dehydrogenation of $77 \mathrm{nmol} \mathrm{min}^{-1}$ (mg protein $)^{-1}$ was observed in I00 mM-Tris/ $\mathrm{HCl}$ buffer, $\mathrm{pH} 8 \cdot 0$. Under standard assay conditions at $\mathrm{pH} 7 \cdot 0$ the same enzyme preparation showed a specific activity of $330 \mathrm{nmol} \mathrm{min}^{-1}\left(\mathrm{mg}\right.$ protein) ${ }^{-1}$ with respect to reduction of hydroxypyruvate.

Comparison with the hydroxypyruvate reductase from Pseudomonas AMI. The hydroxypyruvate reductase of methanol-grown Pseudomonas AMI is clearly involved in a serine pathway of $\mathbf{C}_{\mathbf{1}}$-assimilation, hence a detailed comparison between the enzymes from Pa. denitrificans and Pseudomonas AMI would be of interest. The latter enzyme has not been purified and fully examined; however, studies with partially purified preparations (Large \& Quayle, 1963; C. W. Bamforth, J. Brannan \& J. R. Quayle, unpublished work) have shown that the enzyme is similar to that from $P a$. denitrificans in respect of $\mathrm{pH}$ optimum, relative specificity towards glyoxylate and oxaloacetate as substrates, and competitive inhibition by citrate. The most striking difference appears in the specificity towards the pyridine nucleotides, NADH rather than NADPH being preferred by the enzyme from Pseudomonas AMI. 


\section{Table 5. Hydroxypyruvate reductase in Pa. denitrificans grown on various carbon sources}

The organism was grown as described in Methods except that methanol was replaced by another growth substrate at the concentration indicated. NADPH-dependent hydroxypyruvate reductase activity was determined at $\mathrm{pH}_{7.0}$ as described in Methods, and is expressed as nmol NADPH consumed $\min ^{-1}$ (mg protein) ${ }^{-1}$.

$\begin{array}{lcc}\text { Growth substrate } & \begin{array}{c}\text { Concn } \\ \text { (mM) }\end{array} & \begin{array}{c}\text { Hydroxypyruvate } \\ \text { reductase } \\ \text { activity }\end{array} \\ \begin{array}{l}\text { Methanol } \\ \text { Methylamine }\end{array} & 50 & 52 \\ \mathrm{H}_{2} / \mathrm{CO}_{2}{ }^{*} & 50 & 52 \\ \text { Glycollate* }_{\text {Acetate* }}^{*} & \mathbf{8 2} \\ \text { Sarcosine } & 25 & 97 \\ \text { Glucose } & 20 & 88 \\ \text { Fructose } & 20 & 80 \\ & 10 & 109 \\ & \text { * Data of Cox \& Quayle (1975). }\end{array}$

\section{Metabolic role of hydroxypyruvate reductase in $\mathrm{Pa}$. denitrificans}

The presence of hydroxypyruvate reductase activity in an organism might be symptomatic of one of several metabolic roles: (i) conversion of the $\mathrm{C}_{3}$-skeleton of serine to phosphoglycerate in the serine pathway of carbon assimilation during growth on $\mathrm{C}_{1}$-compounds as in Pseudomonas AMI (Quayle, I972); (ii) conversion of tartrate to glycerate as in Pseudomonas putida and Ps. acidovorans during growth on tartrate (Kohn \& Jakoby, I968a); (iii) as a tartronate semialdehyde reductase in the glycerate pathway of biosynthesis from glycollate or glyoxylate as in pseudomonads and Escherichia coli (Kornberg, 1966); (iv) as a tartronate semialdehyde reductase during growth on glucarate as in enterobacteria (Wood, I972); (v) conversion of glycerate to serine in a non-phosphorylated pathway of serine biosynthesis, as suggested for mammalian tissue (Willis \& Sallach, 1962).

Possibility (i) is unlikely because $P a$. denitrificans utilizes the ribulose diphosphate cycle during growth on methanol (Cox \& Quayle, 1975). Possibility (ii) is not applicable because the organism does not grow appreciably on D-, L- or meso-tartrate. Possibility (iii) is excluded because the organism grows on glycollate and glyoxylate by the $\beta$-hydroxyaspartate pathway and not the glycerate pathway (Kornberg \& Morris, I965). Possibility (iv) is excluded because the organism does not grow appreciably on glucarate. With regard to possibility (v), assay of cell-free extracts of Pa. denitrificans showed the presence of the three enzymes of the phosphorylated pathway of serine biosynthesis: phosphohydroxypyruvate reductase, phosphoserine aminotransferase and phosphoserine phosphatase at specific activities of 4, 7 and $5 \mathrm{nmol} \mathrm{min}^{-1}$ (mg protein $)^{-1}$ respectively. Thus it does not seem likely that $P a$. denitrificans is an exception to the general rule that bacteria appear to use the phosphorylated rather than the non-phosphorylated pathway of serine biosynthesis (see Harder \& Quayle, I97I $a$ ) and hence there is no evidence in support of possibility (v).

The specific activity of hydroxypyruvate reductase remains at a low constant level during growth of the organism on a variety of substrates (Table 5). This gives no indication of any special role for the enzyme during metabolism of a single class of substrate.

\section{DISCUSSION}

It has been known for some time that extracts of $\mathrm{Pa}$. denitrificans catalyse high rates of reduction of oxaloacetate and hydroxypyruvate with NADPH as electron donor (Kornberg \& Morris, 1965; Gibbs, 1966). By virtue of this property, extracts of the organism have 
been used to furnish coupling enzyme(s) for measurement of oxaloacetate or hydroxypyruvate production, especially when use of NADPH can circumvent high levels of NADH oxidase activity (Blackmore \& Quayle, 1970; Harder \& Quayle, 1971 $b$ ). The present work shows that the greatest activity of NADPH-linked oxaloacetate reduction in crude extracts is due to malate dehydrogenase which can use either $\mathrm{NAD}^{+}$or $\mathrm{NADP}^{+}$; at $\mathrm{pH} 7 \cdot 0$, the former coenzyme gives rates of reaction four- to fivefold higher than the latter. A smaller contribution to the overall NADP-linked oxaloacetate reductase activity comes from a hydroxypyruvate reductase which can use either $\mathrm{NADPH}$ or $\mathrm{NADH}$; at $\mathrm{pH} 7 \cdot 0$, the former coenzyme gives two- to threefold higher reaction rates than the latter. The hydroxypyruvate reductase activity is due to the latter enzyme and cannot be ascribed to lack of specificity of the malate dehydrogenase.

The hydroxypyruvate reductase appears to be a constitutive enzyme of $P$ a . denitrificans without an obvious metabolic role. There is, however, a possible connection between its presence and that of a similar enzyme in Ps. acidovorans and Pseudomonas putida (Kohn \& Jakoby, $1968 a, b)$. These two organisms grow on tartrate by the following sequence:

$$
\begin{aligned}
& \mathrm{HO}_{2} \mathrm{C} . \mathrm{CHOH} . \mathrm{CHOH} . \mathrm{CO}_{2} \mathrm{H}+\mathrm{NAD}^{+} \longrightarrow \underset{\text { tartrate }}{\mathrm{HO}_{2} \mathrm{C} . \mathrm{CO} . \mathrm{CHOH} . \mathrm{CO}_{2} \mathrm{H}+\mathrm{NADH}} \\
& \mathrm{HO}_{2} \text { C.CO.CHOH. } \mathrm{CO}_{2} \mathrm{H}+\mathrm{NADH} \longrightarrow \underset{\text { glycerate }}{\mathrm{HO}_{2} \mathrm{CH} . \mathrm{CHOH}} \mathrm{CH}_{2} \mathrm{OH}+\mathrm{CO}_{2}+\mathrm{NAD}^{+}
\end{aligned}
$$

Oxaloglycollate undergoes non-enzymic isomerization to dihydroxyfumarate and decarboxylation to hydroxypyruvate and tartronate semialdehyde:

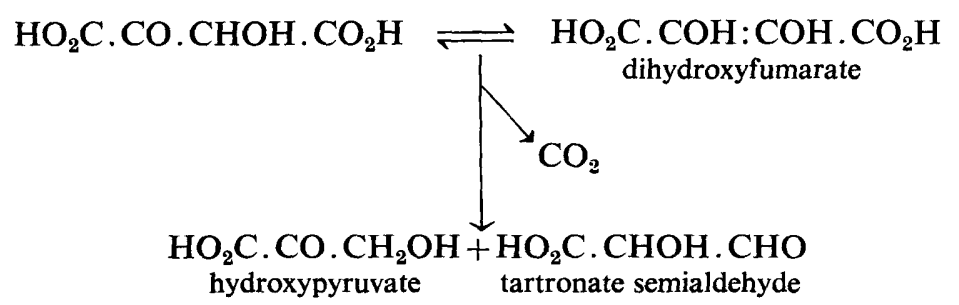

The two organisms possess constitutive hydroxypyruvate and tartronate semialdehyde reductases capable of reducing both substrates to glycerate.

Paracoccus denitrificans grows on glycollate or glyoxylate by the $\beta$-hydroxyaspartate pathway which involves condensation of glyoxylate and glycine derived therefrom to $\beta$-hydroxyaspartate, followed by deamination to oxaloacetate:

$$
\mathrm{HO}_{2} \mathrm{C} . \underset{\beta \text {-hydroxyaspartate }}{\mathrm{CHOH}} \mathrm{CHNH}_{2} \cdot \mathrm{CO}_{2} \mathrm{H} \longrightarrow \mathrm{HO}_{2} \mathrm{C} . \mathrm{CO} \cdot \mathrm{CH}_{2} \cdot \mathrm{CO}_{2} \mathrm{H}+\mathrm{NH}_{3}
$$

If $\beta$-hydroxyaspartate were, to some extent, deaminated in vivo by a non-specific transaminase, formation of oxaloglycollate would result, with the possibility of its non-enzymic decarboxylation to hydroxypyruvate and tartronate semialdehyde. It may therefore be speculated that $P$ a . denitrificans, $P$ s. acidovorans and $P$ s. putida possess a hydroxypyruvate reductase as a scavenger, returning debris derived from oxaloglycollate breakdown to mainstream metabolism. It is difficult to devise an experimental test for this suggestion, but it may be noted that scavenging roles have been proposed for other enzymes, e.g. glucokinase in $E$. coli (Fraenkel \& Vinopal, 1973).

The problem of supernumerary hydroxypyruvate reductase may be a minor one in some areas of metabolism but not in $\mathrm{C}_{1}$-metabolism. Hydroxypyruvate reductase is widely used as a marker enzyme for the presence of the serine pathway of $\mathrm{C}_{1}$-assimilation, sometimes at low specific activities and with little other supporting evidence. Several examples of such usage can be seen in papers published in Microbial Growth on $C_{1}$-Compounds (Proceedings of the International Symposium on Microbial Growth on $\mathrm{C}_{1}$-Compounds, Tokyo, 1974); 
see also Kato et al. (1977). It should be emphasized that other evidence is needed, e.g. presence of other enzymes of the serine pathway and their induction or derepression during growth on $\mathrm{C}_{\mathbf{1}}$-compounds. The danger of uncritical acceptance of the mere presence of low levels of hydroxypyruvate reductase as a diagnostic marker is underlined by its apparently transvestite appearance in $\mathbf{P a}$. denitrificans growing autotrophically on methanol.

We thank Miss J. Brannan and Miss P. A. Greenland who carried out some of the initial studies as part of their undergraduate research projects and the Science Research Council for financial support under grant no. G/RA 04934. We also thank Dr J. P. van Dijken for many helpful discussions.

\section{REFERENCES}

Blackmore, M. A. \& Quayle, J. R. (I970). Microbial growth on oxalate by a route not involving glyoxylate carboligase. Biochemical Journal I18, 53-59.

CoX, R. B. \& QUAYLE, J. R. (1975). The autotrophic growth of Micrococcus denitrificans on methanol. Biochemical Journal 150, 569-571.

Davis, B. J. (1964). Disc electrophoresis. Methods and application to human serum proteins. Annals of the New York Academy of Sciences 121, 404-427.

Dawson, R. M. C., Elliotr, D. C., ElliotT, W. H. \& JONES, K. M. (1969). Data for Biochemical Research, and edn. Oxford: Clarendon Press.

Dixon, M. (1953a). A nomogram for ammonium sulphate solutions. Biochemical Journal 54, 457458.

DIxon, M. (1953 $b$ ). The determination of enzyme inhibitor constants. Biochemical Journal 55, 170171.

EIsenthal, R. \& Cornish-Bowden, A. (1974). The direct linear plot. A new graphical procedure for estimating enzyme kinetic parameters. Biochemical Journal 139, 71 5-720.

FRAENKEL, D. G. \& ViNOPAL, R. T. (1973). Carbohydrate metabolism in bacteria. Annual Review of Microbiology 27, 69-100.

GIBBS, R. G. (1966). The enzymology of the $\beta$-hydroxyaspartate pathway. Ph.D. thesis, University of Leicester.

HARDER, W. \& QUAYLe, J. R. (I97I $a$ ). The biosynthesis of serine and glycine in Pseudomonas AMI with special reference to growth on carbon sources other than $C_{1}$ compounds. Biochemical Journal 121, 753-762.

HARDER, W. \& QUAYLE, J. R. (197I $b$ ). Aspects of glycine and serine biosynthesis during growth of Pseudomonas AMI on $\mathrm{C}_{1}$ compounds. Biochemical Journal 121, 763-769.

Heptinstall, J. \& Quayle, J. R. (1970). Pathways leading to and from serine during growth of $P$ seudomonas AMI on $\mathrm{C}_{1}$ compounds or succinate. Biochemical Journal n17, 563-572.

HirsCh-Kolb, H. \& GREenBerG, D. M. (197I). Phosphoserine aminotransferase (sheep brain). Methods in Enzymology 17B, 331-334.
Kato, N., Tsuit, K., OHashi, H., Tani, Y. \& Ogata, K. (I977). The assimilation pathways of $C_{1}$ compounds in Streptomyces sp. No. 239 during growth on methanol. Agricultural and Biological Chemistry 4I, 29-34.

KOHN, L. D. \& JAKOBY, W. B. (1968a). Tartaric acid metabolism. III. The formation of glyceric acid. Journal of Biological Chemistry 243, 2465-2471.

KoHN, L. D. \& JAKOBY, W. B. (1968b). Tartaric acid metabolism. VII. Crystalline hydroxypyruvate reductase (D-glycerate dehydrogenase). Journal of Biological Chemistry 243, 2494-2499.

KORNBERG, H. L. (1966). Anaplerotic sequences and their role in metabolism. Essays in Biochemistry 2, I-3I.

KORNBERG, H. L. \& MORRIS, J. G. (1965). The utilization of glycollate by Micrococcus denitrificans: the $\beta$-hydroxyaspartate pathway. Biochemical Journal 95, 577-586.

LaRge, P. J. \& CARTer, R. H. (1973). Specific activities of enzymes of the serine pathway of carbon assimilation in Pseudomonas aminovorans and Pseudomonas MS grown on methylamine. Biochemical Society Transactions I, I29I-I 293.

LARGE, P. J. \& QuaYle, J. R. (1963). Microbial growth on $\mathrm{C}_{1}$ compounds. Enzyme activities in extracts of Pseudomonas AMI. Biochemical Journal 87, 386-396.

LoWry, O. H., Rosebrough, N. J., FarR, A. L. \& Randall, R. J. (I95I). Protein measurement with the Folin phenol reagent. Journal of Biological Chemistry 193, 265-275.

Pizer, C. I. \& Sugimoto, E. (1971). 3-Phosphoglycerate dehydrogenase (Escherichia coli). Methods in Enzymology 17B, 325-33I.

QUAYLE, J. R. (1972). The metabolism of one-carbon compounds by micro-organisms. Advances in Microbial Physiology 7, I 19-203.

Willis, J. E. \& Sallach, H. J. (I962). Evidence for a mammalian D-glyceric dehydrogenase. Journal of Biological Chemistry 237, 910-915.

Wood, W. A. (1972). 2-Keto-3-deoxy-6-phosphogluconic and related aldolases. In The Enzymes, 3rd edn, vol. 7, pp. 28I-302. Edited by P. D. Boyer. New York \& London: Academic Press. 